\title{
Manpower and workload in adult renal medicine in the United Kingdom 1975-82
}

\author{
N F JONES, F J GOODWIN, A P ROBERTS
}

The Royal College of Physicians' Committee on Renal Medicine and the Executive Committee of the Renal Association recently conducted a survey of manpower and workload in adult renal medicine in the United Kingdom. This report describes the findings of the survey and compares them with a similar study conducted in $1975 .{ }^{1}$

\section{Present survey}

MANPOWER

A questionnaire was sent to the directors of all NHS renal units in the United Kingdom providing renal replacement therapythat is, dialysis with or without transplantation. All such units in the United Kingdom submit yearly accounts of their activity to the registration committee of the European Dialysis and Transplant Association, thus facilitating their identification. The questionnaire elicited details of present senior and junior medical staffing, the proportion of time spent practising nephrology, the retirement dates of senior staff, and new posts planned. Medical associate specialists or clinical assistants were included. Details were also requested of senior and junior academic posts, funded either by the University Grants Committee or by other sources, together with individuals currently in research posts, however funded, who planned a career in nephrology in the United Kingdom. The completion date for the questionnaire was 31 March 1982.

Some physicians practise nephrology outside renal units that provide full renal replacement therapy, as defined above, and considerable efforts were made to identify these doctors. A well known nephrologist in each NHS region was asked to supply details of physicians practising part time or whole time nephrology outside recognised renal units in that region. Individuals thus identified were then sent a questionnaire designed to establish the proportion of their time spent practising nephrology and the special services offered within that practice. Dates of retirement and information about the nature of the post to be created by their retirement were also requested. The list of physicians so identified was then circulated to all directors of renal units with the request that omissions or errors should be notified.

Any reply considered to be ambiguous or uncertain was checked by personal contact with the physician concerned. In the following

\section{St Thomas's Hospital, London SE1}

N F JONES, MD, FRCP, consultant physician (chairman, Royal College of Physicians' Committee on Renal Medicine)

The London Hospital, London $E 1$

F J GOODWIN, MD, FRCP, consultant physician (formerly secretary, the Renal Association)

Charing Cross Hospital Medical School, London W6

A P ROBERTS, PHD, MIBIOL, senior lecturer in medical microbiology

Correspondence to: Dr N F Jones. analysis an individual holding both NHS and university appointments was included in only one category, after consultation with the unit concerned.

The data used for the 1975 Renal Association survey were reexamined and any anomalies checked personally with the nephrologists concerned.

\section{WORKLOAD}

Assessment of workload was limited to the provision of dialysis and transplantation, and this activity was obtained from the yearly reports of the Registration Committee of the European Dialysis and Transplant Association. Details of the dialysis and transplantation activity in each NHS region during the years ending 31 December 1975 and 31 December 1981 were related to the manpower data obtained by the 1975 Renal Association survey and by the present study. We emphasise that this definition of nephrological workload ignores the care of patients with acute renal failure and the management of the many patients with kidney disease which has not progressed to end stage renal failure.

\section{Results}

MANPOWER

Tables I and II present details of the population and nephrological manpower for each NHS region in 1975 and 1982. Changes in regional populations were very small. The number of NHS consultants in post rose from 71 in 1975 to 87 in 1982, an increase of $22.5 \%$, whereas the number of senior registrars rose from 15 to $29(93.3 \%)$. The percentage increase in the number of senior registrar sessions in nephrology was not quite as large $(77.4 \%)$, but none the less a more rapid expansion of the senior registrar grade compared with consultant staff was apparent. The increases in registrar and senior house officer grades between 1975 and 1982 were also greater than that in the consultant grade, but the percentage increases in nephrological sessions provided were only slightly greater than that for the consultant staff. This indicates greater participation by senior house officers and registrars in rotation schemes in which nephrology was only one part. In addition to the manpower described in tables I and II, the survey also identified 22 research fellows who planned careers in renal medicine in Britain.

The sessions provided by senior university staff-that is, senior lecturers and above-increased by $42 \%$ and those provided by lecturers rose by $52 \%$. Tables I and II show that total junior NHS and university staff increased from 148 in 1975 to 207 in $1982(39.9 \%)$, although the increase in sessions provided was less $(29.3 \%)$. Total senior NHS and university staff rose by 23 , an increase of $24 \%$, and their sessional contribution by 148 , an increase of $26 \%$.

The figure shows the relation between population and manpower (represented by the total number of doctor sessions in nephrology per week) in each region in 1975 and 1982 . The data for 1975 were replotted from the previous survey ${ }^{1}$ and an error in the figures for Wessex corrected. In most regions manpower increased during this period and the correlation coefficient for the relation between manpower and workload increased from $r=0.582$ in 1975 to $r=0.703$ in 1982. This 


\begin{tabular}{|c|c|c|c|c|c|c|c|c|c|c|}
\hline \multirow[b]{2}{*}{ Region } & \multicolumn{2}{|c|}{ Population (millions) } & \multicolumn{2}{|c|}{$\begin{array}{l}\text { No of consultants } \\
\text { (sessions/week) }\end{array}$} & \multicolumn{2}{|c|}{$\begin{array}{c}\text { No of professors, readers, } \\
\text { senior lecturers } \\
\text { (sessions/week) }\end{array}$} & \multicolumn{2}{|c|}{$\begin{array}{l}\text { Total No of senior staff } \\
\quad \text { (sessions/week) }\end{array}$} & \multicolumn{2}{|c|}{$\begin{array}{l}\text { No of sessions per } \\
\text { million population }\end{array}$} \\
\hline & 1975 & 1982 & 1975 & 1982 & 1975 & 1982 & 1975 & 1982 & 1975 & 1982 \\
\hline $\begin{array}{l}\text { North East Thames } \\
\text { North West Thames } \\
\text { South East Thames } \\
\text { South West Thames } \\
\text { Northern } \\
\text { North Western } \\
\text { Mersey } \\
\text { West Midlands } \\
\text { Yorkshire } \\
\text { Trent } \\
\text { Oxford } \\
\text { East Anglian } \\
\text { Wessex } \\
\text { South Western } \\
\text { Wales } \\
\text { Northern Ireland } \\
\text { Scotland }\end{array}$ & $\begin{array}{l}3 \cdot 7 \\
3.5 \\
3 \cdot 6 \\
2 \cdot 9 \\
3 \cdot 1 \\
4 \cdot 1 \\
2 \cdot 5 \\
5 \cdot 2 \\
3 \cdot 6 \\
4.5 \\
2 \cdot 2 \\
1.8 \\
2 \cdot 6 \\
3 \cdot 1 \\
2.8 \\
1.5 \\
5 \cdot 2\end{array}$ & $\begin{array}{l}3 \cdot 7 \\
3 \cdot 5 \\
3 \cdot 5 \\
3 \cdot 0 \\
3 \cdot 1 \\
4 \cdot 0 \\
2 \cdot 4 \\
5 \cdot 2 \\
3 \cdot 6 \\
4 \cdot 5 \\
2 \cdot 3 \\
1 \cdot 9 \\
2 \cdot 7 \\
3 \cdot 0 \\
2 \cdot 8 \\
1 \cdot 5 \\
5 \cdot 2\end{array}$ & $\begin{array}{l}8(64) \\
4(35) \\
10(67) \\
2(8) \\
5(43) \\
4(24) \\
3(15) \\
9(42) \\
4(29) \\
5(34) \\
1(11) \\
2(12) \\
1(8) \\
3(15) \\
3(13) \\
2(22) \\
5(32)\end{array}$ & $\begin{aligned} 9(64) \\
5(30) \\
11(73) \\
2(12) \\
7(44) \\
7(42) \\
3(21) \\
7(36) \\
5(41) \\
7(48) \\
1(11) \\
3(15) \\
1(8) \\
4(31) \\
3(13) \\
3(33) \\
9(57 \cdot 5)\end{aligned}$ & $\begin{array}{l}6(23) \\
3(15) \\
1(4) \\
1(4) \\
1(3) \\
1(2) \\
1(3) \\
1(4) \\
2(14) \\
1(4) \\
5(25)\end{array}$ & $\begin{array}{l}2(13) \\
5(24) \\
2(14) \\
3(6) \\
1(2) \\
3(17) \\
1(5) \\
1(4) \\
2(14) \\
1(4) \\
1(5 \cdot 5) \\
8(35)\end{array}$ & $\begin{array}{r}14(87) \\
7(50) \\
11(71) \\
2(8) \\
6(47) \\
5(27) \\
3(15) \\
10(46) \\
4(29) \\
6(37) \\
2(15) \\
2(12) \\
3(22) \\
3(15) \\
4(17) \\
2(22) \\
10(57)\end{array}$ & $\begin{array}{l}11(77) \\
10(54) \\
13(87) \\
2(12) \\
10(50) \\
8(44) \\
3(21) \\
10(53) \\
5(41) \\
8(53) \\
2(15) \\
3(15) \\
3(22) \\
4(31) \\
4(17) \\
4(38.5) \\
17(92.5)\end{array}$ & $\begin{aligned} 23 \cdot 3 \\
14 \cdot 4 \\
19 \cdot 6 \\
2 \cdot 8 \\
15 \cdot 0 \\
6 \cdot 6 \\
6 \cdot 0 \\
8 \cdot 5 \\
8 \cdot 1 \\
8 \cdot 1 \\
6 \cdot 9 \\
6 \cdot 8 \\
8 \cdot 5 \\
4 \cdot 8 \\
6 \cdot 1 \\
14 \cdot 7 \\
10 \cdot 9\end{aligned}$ & $\begin{array}{r}20.8 \\
15.4 \\
24.9 \\
4.0 \\
16.1 \\
11.0 \\
8.8 \\
10.2 \\
11.4 \\
11.8 \\
6.5 \\
7.9 \\
8 \cdot 1 \\
10 \cdot 1 \\
6.1 \\
25.7 \\
17.8\end{array}$ \\
\hline $\begin{array}{l}\text { Total } \\
\text { Increase } \\
\sigma_{0}^{\prime} \text { Increase }\end{array}$ & $55 \cdot 9$ & $55 \cdot 9$ & $71(474)$ & $\begin{array}{l}87(579 \cdot 5) \\
16(105 \cdot 5) \\
22 \cdot 5(22 \cdot 2)\end{array}$ & $23(101)$ & $\begin{array}{l}30(143 \cdot 5) \\
7(42 \cdot 5) \\
30 \cdot 4(42 \cdot 1)\end{array}$ & $94(575)$ & $\begin{array}{c}117(723 \cdot 0) \\
23(148 \cdot 0) \\
24 \cdot 5(26 \cdot 0)\end{array}$ & & \\
\hline
\end{tabular}

indicates a tendency for the discrepancies between manpower and population apparent in 1975 to have decreased, but the increase in the correlation was not statistically significant $(z=0.550 ; p>0.05)$.

Thirty nine physicians were identified who were working in nephrology outside recognised renal units compared with 12 such physicians recorded in the 1975 survey. These 39 physicians estimated that they provided a total of 78.5 sessions a week in nephrology.

\section{WORKLOAD}

Table III shows the workload in providing renal replacement therapy in 1975 and 1981. The term "total patient stock" refers to all patients with chronic renal failure receiving treatment either by regular dialysis (of all types) or by transplantation. Table III also records new patients beginning renal replacement therapy and transplant operations performed during the two years concerned. Total patient stock increased by $4335(118 \%)$ from 1975 to 1981 . A total of 1421 new patients were included in renal replacement programmes in 1981 compared with 897 in 1975 , an increase of $58 \%$. The yearly transplantation rate was also greater in 1981 than in 1975, but the percentage increase $\left(33^{\circ}\right.$ ) was smaller than the increases in total patient stock and in new patients starting replacement therapy. Table III also relates total patient stock to population in each region.

\section{Discussion}

This survey identified 29 senior registrars training in nephrology in 1982, together with 15 lecturers in university departments and 22 research fellows planning careers in renal medicine in Britain. In the five year period 1983-7 inclusive only two of the 87 existing consultants in renal medicine will reach the retirement age of 65 . In addition, two of the 39 consultants practising nephrology outside recognised renal units and three senior university staff are due to retire. In the 10 year period 1983-92 corresponding figures for expected retirements are eight consultant nephrologists working in recognised renal units, seven consultants working outside these units, and five senior university staff. There is no certainty that the retiring university staff will be replaced by doctors specialising in nephrology; indeed, it is likely that many will not. Similarly, retiring consultants who practised nephrology outside recognised renal units may not be replaced by doctors with a similar special interest. We emphasise that these figures take no account of early retirement or death in post and therefore underestimate the number of posts that will become vacant. Moreover, no account is taken of new posts that will be created in the periods concerned. Nevertheless, the present imbalance between the number of junior staff in training at senior registrar level and the likely number of vacancies, particularly in the next five years, is obvious and disturbing.

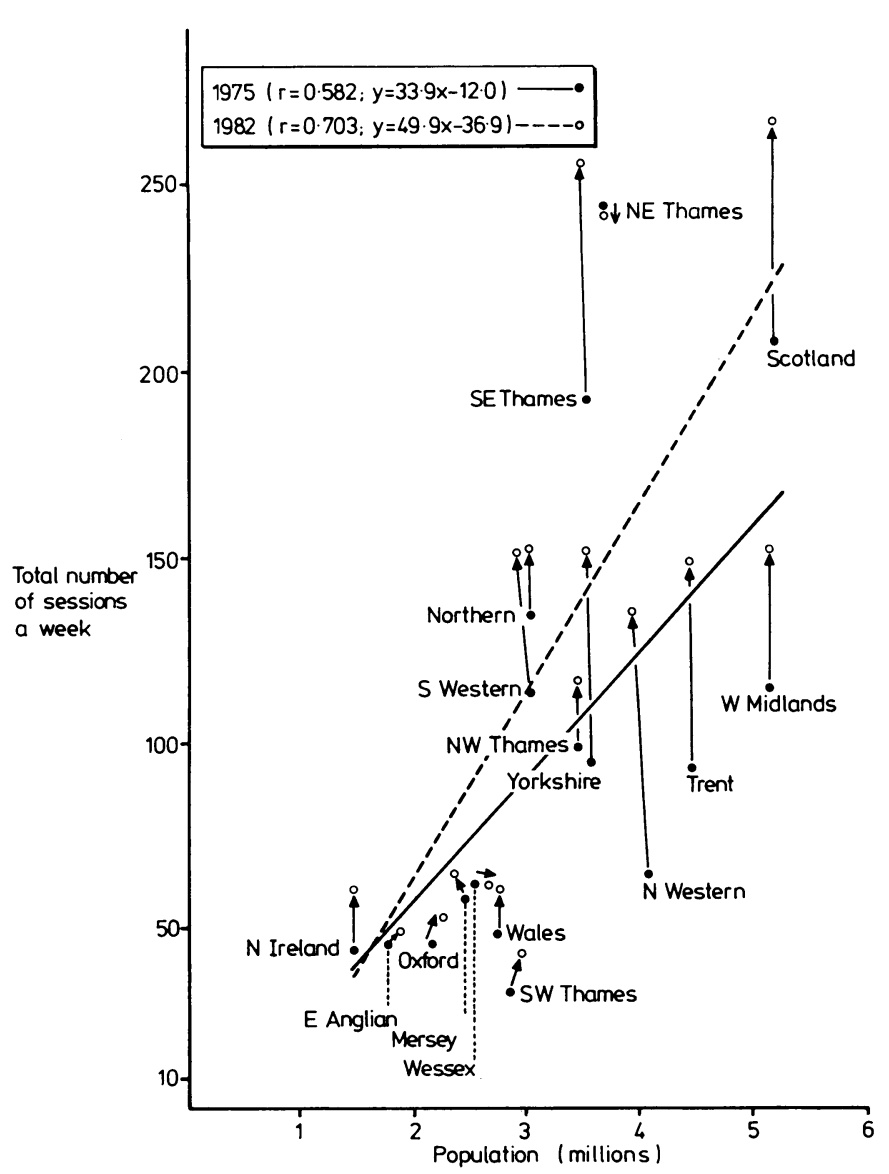

Relation between population and total number of doctor sessions a week provided in each region in 1975 and 1982. Change in manpower for each region between 1975 and 1982 indicated by arrow. Regression lines do not differ significantly with respect to slope, elevation, or residual variance (variance not explained by regression : $p>0 \cdot 1)$; nor is rise in correlation coefficient statistically significant $(\mathrm{z}=0.550 ; \mathrm{p}>0.05)$.

The expansion of the workload in nephrology between 1975 and 1981 shown in this study indicates clearly that the solution to this problem is the creation of more consultants in the specialty. During this interval the total stock of patients receiving renal replacement therapy rose by $118 \%$, whereas the number of NHS consultants in nephrology increased by only $22.5 \%$. Moreover, the yearly rate at which new patients were accepted for dialysis or transplantation was $58 \%$ higher in 1981 than in 
TABLE II- Funior medical staff in nephrology

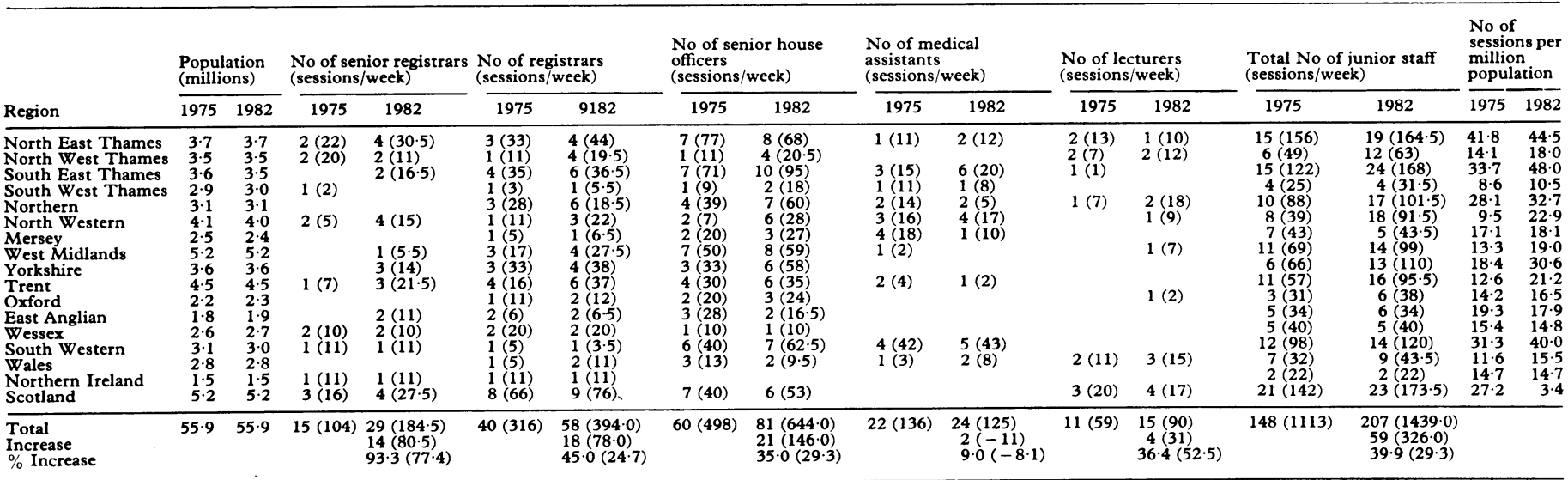

TABLE III-Workload in renal replacement therapy

\begin{tabular}{|c|c|c|c|c|c|c|c|c|c|c|}
\hline \multirow[b]{2}{*}{ Region } & \multicolumn{2}{|c|}{ Population (millions) } & \multicolumn{2}{|c|}{ Total patient stock } & \multicolumn{2}{|c|}{ New patients } & \multicolumn{2}{|c|}{ Transplant operations } & \multicolumn{2}{|c|}{$\begin{array}{c}\text { Total patient stock } \\
\text { per million population }\end{array}$} \\
\hline & 1975 & 1981 & 1975 & 1981 & 1975 & 1981 & 1975 & 1981 & 1975 & 1981 \\
\hline $\begin{array}{l}\text { North East Thames } \\
\text { North West Thames } \\
\text { South East Thames } \\
\text { South West Thames } \\
\text { Northern } \\
\text { North Western } \\
\text { Mersey } \\
\text { West Midlands } \\
\text { Yorkshire } \\
\text { Trent } \\
\text { Oxford } \\
\text { East Anglian } \\
\text { Wessex } \\
\text { South Western } \\
\text { Wales } \\
\text { Northern Ireland } \\
\text { Scotland }\end{array}$ & $\begin{array}{l}3.7 \\
3.5 \\
3 \cdot 6 \\
2.9 \\
3.1 \\
4 \cdot 1 \\
2.5 \\
5.2 \\
3.6 \\
4.5 \\
2.2 \\
1.8 \\
2.6 \\
3.1 \\
2.8 \\
1.5 \\
5.2\end{array}$ & $\begin{array}{l}3 \cdot 7 \\
3.5 \\
3.5 \\
3.0 \\
3.1 \\
4.0 \\
2.4 \\
5 \cdot 2 \\
3.6 \\
4.5 \\
2.3 \\
1.9 \\
2.7 \\
3.0 \\
2.8 \\
1.5 \\
5.2\end{array}$ & $\begin{array}{l}456 \\
355 \\
417 \\
39 \\
306 \\
160 \\
133 \\
244 \\
168 \\
241 \\
182 \\
168 \\
90 \\
137 \\
176 \\
86 \\
312\end{array}$ & $\begin{array}{l}837 \\
558 \\
917 \\
114 \\
557 \\
427 \\
312 \\
601 \\
390 \\
653 \\
367 \\
362 \\
256 \\
336 \\
333 \\
217 \\
768\end{array}$ & $\begin{array}{r}92 \\
59 \\
132 \\
13 \\
66 \\
39 \\
33 \\
68 \\
50 \\
78 \\
34 \\
32 \\
17 \\
37 \\
50 \\
17 \\
80\end{array}$ & $\begin{array}{r}119 \\
79 \\
147 \\
37 \\
91 \\
81 \\
34 \\
117 \\
80 \\
138 \\
59 \\
55 \\
74 \\
66 \\
60 \\
35 \\
149\end{array}$ & $\begin{array}{r}65 \\
56 \\
113 \\
2 \\
38 \\
34 \\
34 \\
64 \\
23 \\
36 \\
28 \\
47 \\
12 \\
17 \\
23 \\
16 \\
50\end{array}$ & $\begin{array}{r}73 \\
50 \\
142 \\
14 \\
34 \\
37 \\
40 \\
69 \\
37 \\
69 \\
39 \\
40 \\
49 \\
33 \\
41 \\
24 \\
86\end{array}$ & $\begin{array}{l}123 \\
101 \\
116 \\
13 \\
99 \\
39 \\
53 \\
47 \\
47 \\
54 \\
83 \\
93 \\
35 \\
44 \\
63 \\
57 \\
60\end{array}$ & $\begin{array}{r}226 \\
159 \\
262 \\
38 \\
180 \\
107 \\
130 \\
116 \\
108 \\
145 \\
160 \\
191 \\
95 \\
112 \\
119 \\
145 \\
148\end{array}$ \\
\hline $\begin{array}{l}\text { Total } \\
\text { Increase } \\
\% \text { Increase }\end{array}$ & $55 \cdot 9$ & $55 \cdot 9$ & 3670 & $\begin{array}{r}8005 \\
4335 \\
118\end{array}$ & 897 & $\begin{array}{r}1421 \\
524 \\
58\end{array}$ & 658 & $\begin{array}{r}877 \\
219 \\
33\end{array}$ & & \\
\hline
\end{tabular}

1975. Data collected by the Registration Committee of the European Dialysis and Transplant Association have repeatedly shown how inadequate is the provision of renal replacement therapy in Britain compared with that of many other developed countries. In 1982 no fewer than 14 other European countries treated more patients with renal failure per million population than did the United Kingdom, ${ }^{2}$ yet there is no evidence that the incidence of renal failure is lower in this country. Moreover, the most recent report by the Registration Committee of the European Dialysis and Transplant Association shows that France, West Germany, and Italy have roughly three, four, and six times as many renal centres respectively as the United Kingdom, for broadly comparable populations. ${ }^{2}$ The 117 total senior staff and 207 total junior staff in nephrology in the United Kingdom contrast with 518 full time and 400 part time nephrologists in France (C Jacobs, personal communication, 1983).

There appears, therefore, to be a strong case for a major expansion of renal services in the United Kingdom, but the associated expense of dialysis technology means that the appointment of a consultant nephrologist to a new post outside existing renal units requires substantial funding. Delegation of this duty to regional health authorities within their present budgets as presently proposed is unrealistic.

We thank the nephrologists of the United Kingdom for their help in producing this report. We also thank the chairman of the Registration Committee of the European Dialysis and Transplant Association (Dr A J Wing) for providing details of the workload.

\section{References}

1 Distribution of nephrological services for adults in Great Britain. Br Med $\mathcal{F}$ 1976;ii:903-6.

2 Wing AJ, Broyer M, Brunner FP, et al. Combined report on regular dialysis and transplantation in Europe, XIII, 1982. Proc Eur Dial Transplant Assoc 1983;20:5-75.

(Accepted 30 January 1984) 